\title{
PRODUCTION OF SERINE CHYMOTRYPSIN-LIKE ELASTASE BY ASPERGILLUS FUMIGATUS STRAINS
}

\author{
M. Guglielminetti ${ }^{1}$, P.D. Piccioni ${ }^{2}$, P. Imdarola ${ }^{3}$, M. Luisett ${ }^{2}$, \& G. Caretta ${ }^{1}$. \\ ${ }^{1}$ Istituto di Micología Medica, \\ ${ }^{2}$ Istitutodi Tisiologia e Malattie Respiratorie IR CCS PoliclinicoS. Matteo, \\ ${ }^{3}$ Dipartimento di Biochimica, Università degli Studi di Pavia, Italy. \\ Address for Correspondence: \\ G. Caretta, Istituto di Micologia Medica, Università degli Studi di Pavia, \\ Via S. Epifanio 14, 27100 Pavia, Italy.
}

Key-Words: Aspergillus fumigatus, elastase, chymotrypsin activity, proteinase.

Palabras clave: Aspergillus fumigatus, elastasa, actividad de quimiotripsina, proteinasa.

\section{SUMMARY}

Thirtyfour Aspergillus fumigatus strains isolated from air, horse-hair, agricultural soil and human samples were screened to evaluate the production of elastase.

Aspergillus fumigatus strains were grown in elastin solid medium, showing a widespread elastin solubilization.

However, isolates from human and agricultural soil samples were found to be the highest elastase producers.

Then, eight out of 34 strains were grown in four different liquid media, on wich we investigated total and specific proteolytic activity. Results from this experiments suggest that the elastase production is induced by the presence of elastin as a substrate and that the elastase is a chymotrypsin like enzyme.

Inhibitory profile showed that the A. fumigatus elastase is a serine proteinase.

\section{INTRODUCTION}

Aspergillus fumigatus Fres. is a widespread thermotolerant species. It is also a pathogenic fungus able to induce a variety of lung disease in man, i.e. allergic aspergillosis fungus balls, and invasive aspergillosis. The later disease is particularly severe in immonocompromised patients. $(2,4)$. It is known that members of the genus Aspergillus may produce a number of proteolytic enzymes $(3,10)$ and it has been suggested that the production of such enzymes may be associatedd with virulence of the fungal strain.

There is an increasing body of evidence sug-

\section{RESUMEN}

[Producción de una elastina semejante a serinaquimiotripsina por cepas the Aspergillus funigatus]

Treinta y cuatro cepas de Aspergillus fumigatus aisladas del aire, crín de caballo, suelo agrícola y del hombre, fueron examinadas con el fin de evaluar la producción de elastasa.

Las cepas de Aspergillus fumigatus fueron cultivadas en un medio sólido con elastina, apreciándose en ella su amplia solubilización por la acción del hongo.

Los aislamientos fúngicos provenientes de muestras aisladas del hombre y de suelos agricolas fueron detectados como los más altos productores de elastasa.

Ocho de las 34 cepas fueron desarrolladas en 4 diferentes medios líquidos en las cuales se investigó la actividad proteolítica total y específica. Los resultados de este experimento sugieren que la producción de elastasa es inducida por la presencia de elastina como sustrato y que la primera es una enzima semejante a la quimiotripsina.

El perfil inhibitorio comprobó que la elastina de A. fumigatus, es una serina-proteinasa.

gesting that $A$. fumigatus may produce an extracellular proteinase able todegrade elastin $(4,9,12,5)$ and that such an elastase is related to the ability of $A$. fumigatus to induce invasive aspergillosis in animal models (5).

In this contribution, we examined in vitro elastase production by $34 \mathrm{~A}$. fumigatus strains isolated from different sources (soil, plant, human and horsehair) and we achieved a partial characterization of this enzyme in members of this species group. 
The reasons why Aofuratgrabus is more invasive than the other species of the genus remain as unexplained: we will present and discuss some of our own experimental data concerning the elastase production from these strains in relation to their ecology and to pathogenic activity.

\section{MATERIALS AND METHODS}

\section{Origin of Adumigatus strmins}

The majority of the 34 Asfumigutus strains used in this study were freshly isolated from varoius sources such as air ( 7 strains), horse-hair (2 strains), human sputum or bronchoaspirate (10strains), and 15 strains isolated from agricultural soils (wheat-corn, ricefield soil) and grapewine leaf.

\section{Elastase production in solid meding}

The strains were cultured $\left(25^{\circ} \mathrm{C}\right)$ on Czapekagar (Biolife) until sufficient growth had occurred. The cultures were used to provide the inoculum required; spores were collected in sterile $0.1 \%$ Tween 80 (polyoxyethylene Sorbitan monooleate) and a drop of spore suspension at the concentration of $10^{7} / \mathrm{ml}$ was inoculated, in a central spot, onto agar medium $(25 \mathrm{ml}$ in Petri dishes) containing elastin, according to Kothary et al. (5).

Cultures were incubated at $37^{\circ} \mathrm{C}$ for 7 days, elastase activity was detected visually as a clearing zone around and beneath the colony.

\section{Growth in liquid media}

Eight A.fumigatus strains showing to bestrong extracellular elastase producers, were tested for the production of elastase in the following liquid media: CzapekDox broth (Biolife); $\mathrm{YCB}+$ peptone $[0.2 \% \mathrm{YCB}, 0.2 \%$ peptone (Difco), in 0.05 M borate buffer pH 7.6]; elastin [0.2\% soluble bovine neck ligament elastin (Elastin products co.), $[0.2 \% \mathrm{YCB}$ in $0.05 \mathrm{M}$ borate buffer, $\mathrm{pH} 7.6$ ]; and elastin +albumin [elastin medium $+0.05 \%$ bovine albumin (Sigma)], according to Rhodes et al. (14).

Adrop of the suspension obtained as previously described was inoculated into $50 \mathrm{ml}$ of each growth medium in a $250 \mathrm{ml}$. baffled flask and incubated on a shaker, $100 \mathrm{rpm}$ ) at $37^{\circ} \mathrm{C}$ for $72 \mathrm{~h}$.

The culture broth was filtered on paper (Whatman n.4) and finally concentrated approximately 33 fold by ultrafiltration (YM10 membranes, Amicon). Samples were divided in aliquotes and kept at $-20^{\circ} \mathrm{Cuntil}$ needed.

A sample of each medium without fungus in- oculation, was processed in the same fashion and used as control.

Speciific proteolytic activity

To this aim we used the azocasein assay according to the procedure of Barrett (1). Briefly, 250 ul of each sample were incubated with $0.5 \%$ azocasein (Sigma) in TRISHCL $0.2 \mathrm{M}, \mathrm{pH} 7.4$ at $37^{\circ} \mathrm{C}$.

The reaction was stopped after 15 minutes with $200 \mathrm{ul}$ of acetic acid $1 \mathrm{~N}$ and the absorbance read at 440 $\mathrm{nm}$ (PYE Unicam). All samples were run in duplicate with appropriate blanks.

Values were expressed as mg. azocasein degraded over time.

Hydrolysis of symthetic peptide substrates

To this aim 20 ul of each sample were incubated for $1 \mathrm{~h}$. at $3^{\circ} \mathrm{C}$ in phosphate buffer $0.2 \mathrm{M} \mathrm{pH} 7.4$, with the following substrates: N-Succinyl-(Ala) $)_{3}$-pNitroanilide $0.1 \mathrm{mM}$ (SApNa; Sigma); N-methoxysuccinyl-(Ala) ${ }_{2}$-Pro-Val-p-Nitroanilide $0.1 \mathrm{mM}[\mathrm{Me}$ (0)AAPVpNA;Sigma]; Succinyl-(Ala) ${ }_{2}$-Pro-phe-p-Nitroanilide 0,1 mM (SAAPPhep Na; Sigma).

At the end of incubation the reaction was stopped and the absorbance read at $410 \mathrm{~nm}$. The values were expressed as nMoles of substrate hydrolyzed over time.

\section{Protein assay}

Protein concentration was mesured according to Lowry and coworkers (7).

\section{Inhibitory study}

In order to assign the hydrolytic activity on the synthetic peptide substrates to the class of metallo or serine-proteinase, somesamples were preincubated with the metalloproteinase inhibitor EDTA $10 \mathrm{mM}$ (Merck) and the serine-proteinase inhibitor phenylmethylsulfonylfluoride $10 \mathrm{mM}$ (PMSF; Sigma) for 30 minutes. There after we proceeded as above described.

\section{Insoluble elastin degradation}

To this aim we used the method described by Shotton (15). Briefly, $7 \mathrm{ml}$ ofborate buffer $0.02 \mathrm{M}, \mathrm{pH} 8,8$ containingelastin Congo red (Sigma) at concentration of $1 \mathrm{mg} / \mathrm{ml}$, were added to $2 \mathrm{ml}$ of the sample (strain $\mathrm{N}^{\circ} 13$ grown for $72 \mathrm{~h}$ on liquid elastin medium). The mixture was incubated at $37^{\circ} \mathrm{C}$. on shaker and every 15 minutes an aliquot was drawn, centrifuged and the absorbance of the supernate read at $495 \mathrm{~nm}$. In separate tube, elastin Congo red was incubated with $40 \mathrm{ug}$ of porcine 
Table 1. Elastinolytic activity on solid medium of difierent $\mathrm{A}_{\text {. }}$ umigatus strains.

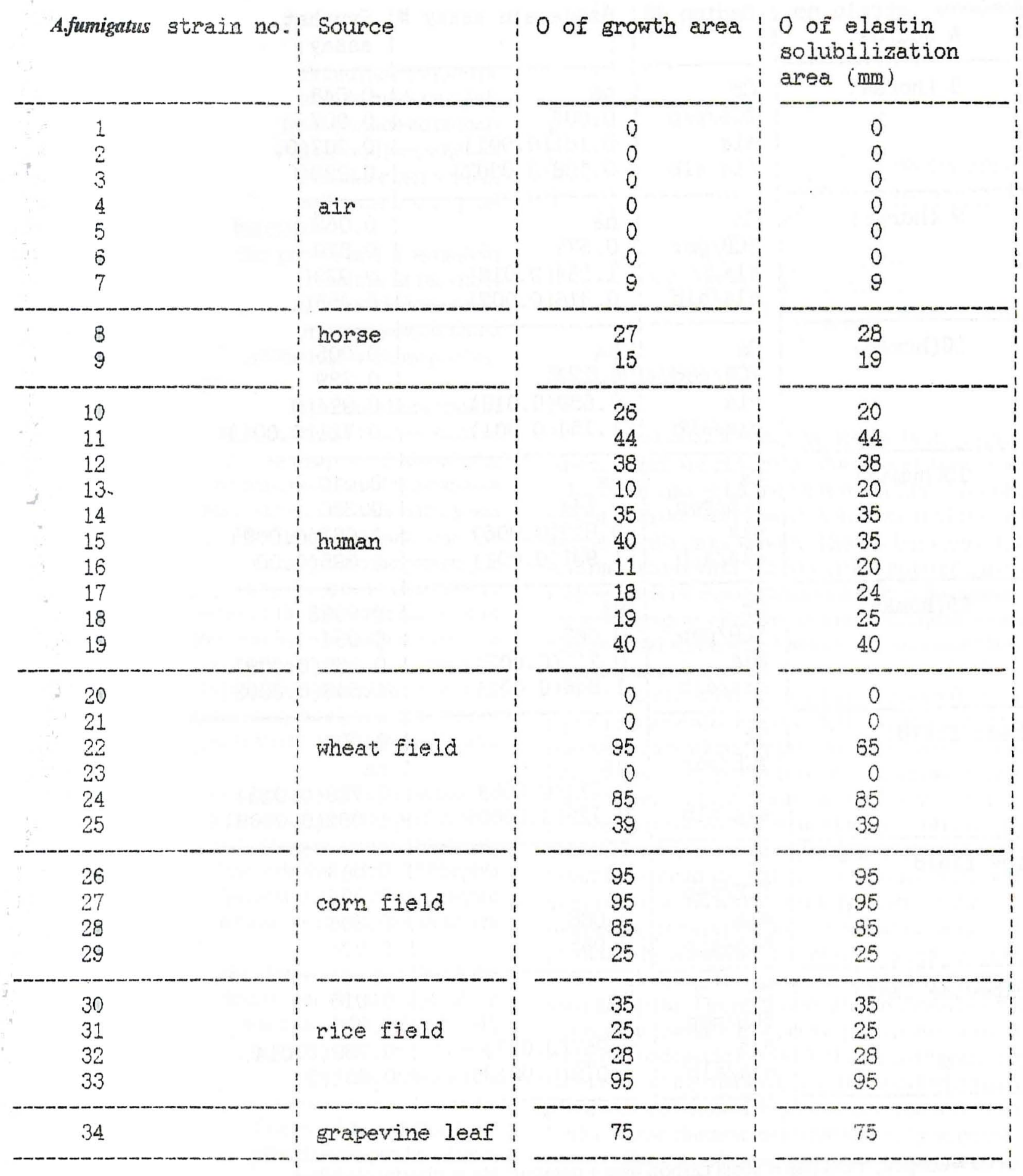


Table 2. Activity of different A.finmigatus strmins on Azocasein and synthetic peptide substrate

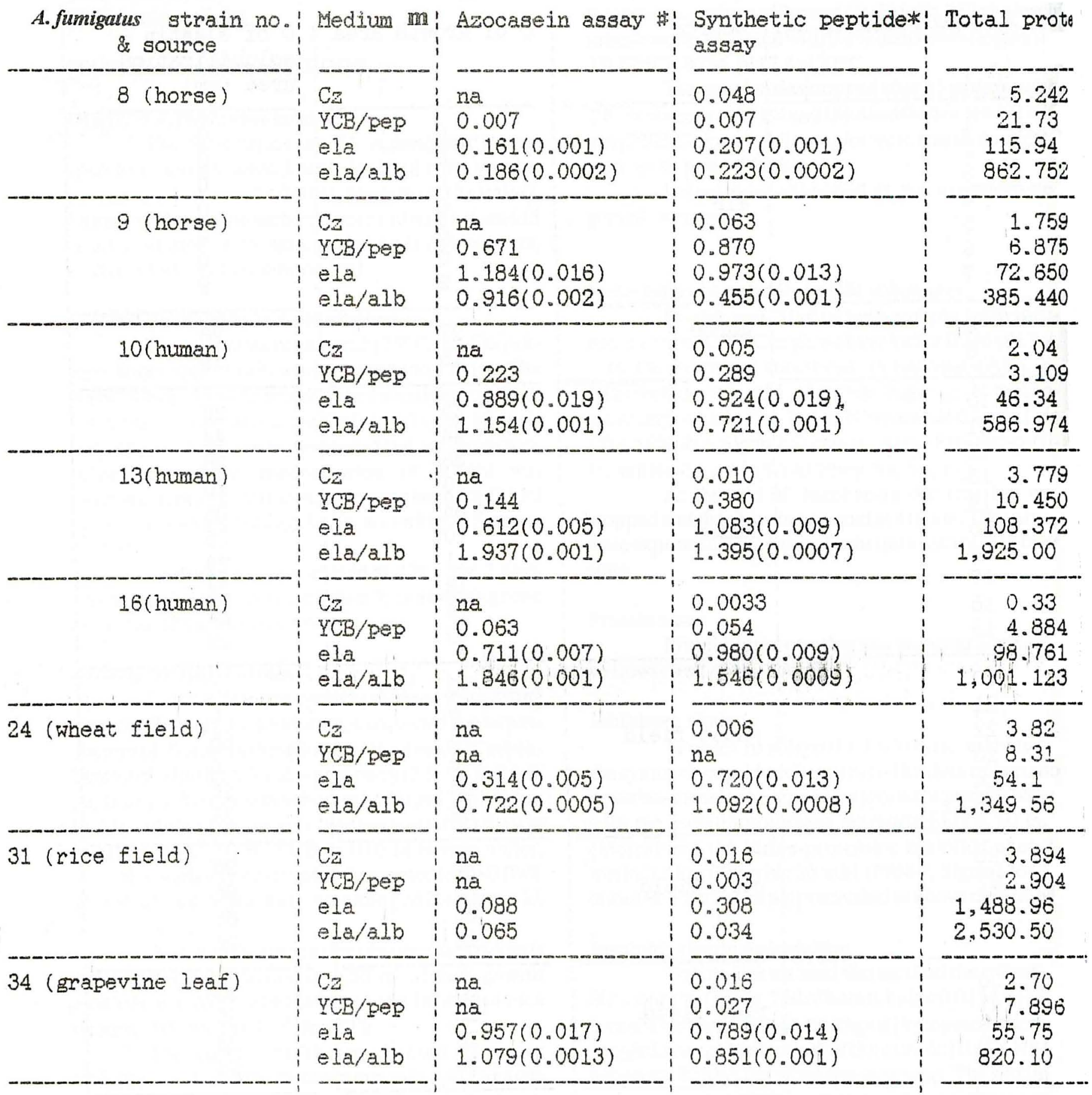

$\mathrm{m} \mathrm{CZ}=\mathrm{Czapek} ; \mathrm{YCB} / \mathrm{pep}=$ yeast carbon base + peptone; ela = elastin; ela/alb = elastin + albumin; \# mg of azocasein degraded in $15 \mathrm{~min}$. In brackets, value normalized per mg of proteins." nMoles of SAAPPhepNA hydrolyzed in $1 \mathrm{~h}$. In brackets, value normalized per $\mathrm{mg}$ of proteins. $\$ \mathrm{mg}$. dl-1. na = no activity 
pancreatic elastase (PPE; Sigma, type IV) and the experiment then proceeded as previously described. Values were expressed as changes of absorbance overtime.

\section{RESULTS}

Table 1 shows the growth and the elastinolytic activity of $A$. fumigatus strains in solid medium. Only one of seven strains isolated from air showed moderate growth and elastinolysis on this medium, whereas almost all the strains isolated from the other sources (human, horse-hair, cultivated soil) were able to grow and to solubilize insoluble elastin.

In some cases the growth and elastinolysis had the same degree (fig. 1A), whereas in the other cases the diameter of elastinolysis exceeded the diameter of growth (fig. 1B). Strains of $A$. fumigarus, isolated from agricultural soils were the high elastase producers.

As it may be ascertained from the inspection of table 2, none of eight strains, selected on the basis of previous results and grown in Czapek liquid medium, revealed a proteolytic activity, as detected by azocasein assay. In five out of the eight strains, this activity was fairly enhanced when the liquid medium was the $\mathrm{YCB}+$ peptone. Adramatic increase in the proteolytic activity was determinated by the growth of strains in elastin medium. In most of the cases the addition of albumin to elastin medium induced only a moderate further increase of proteolytic activity.

With regard to the hydrolysis of the threesynthetic peptide substrates used, the eight strains did not react eitherwith SApNa or $\mathrm{Me}(0) \mathrm{AAPV}$ pNa substrates (data notshown).

By contrast, samples strongly hydrolyzed the SAAPPhepNa substrate, thus suggesting a preferential cleavage of a substrate with phenylalanine residue in $\mathrm{P}_{1}$ position. The results of the hydrolysis of SAAPPhepNa substrate by the $A$. fumigatus strains in different liquid media, stricly parallelled those obtained in the azocasein assay.

Concerning the inhibitory profile of the hydrolytic activity, we found that the cleavage of the SAAPPhepNa substrate was fully abolished by PMSF, whereas it was unaffected by EDTA (data not shown). Therefore we may assign this activity to the class of serine proteinase.

Finally theelastin Congo red degradation assay allowed us to establish that the elastase produced by $A$. fumigatus in elastin medium has a moderate elastinolytic capacity, when compared to the elasti- nolytic capacity of PPE (fig. 2). In fact the elastinolytic capacity of $A$. fumigatus was $7,6 \%$ of the PPE elastinolytic capacity.

\section{Fig 2. Elastin-congo red solubilization}

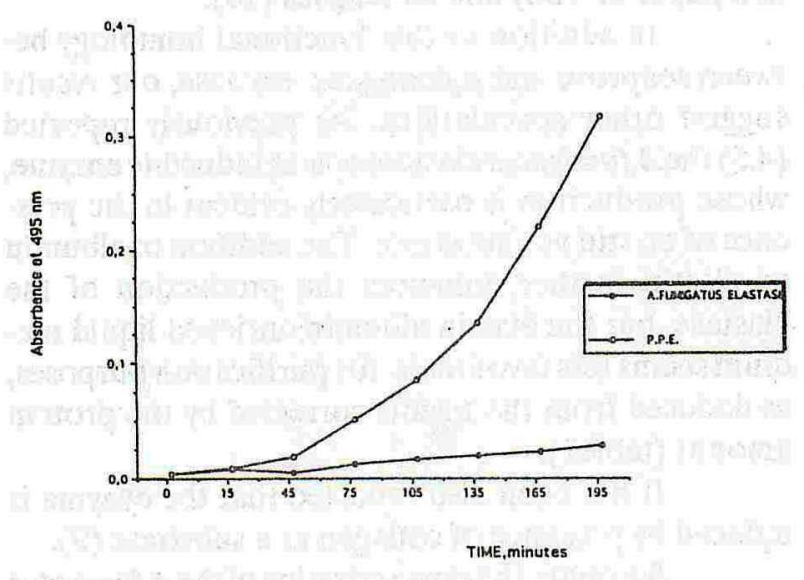

DISCUSSION

Our data show that the most of the $A$. fumigatus strains tested are able to produce an elastase when cultured in agar solid medium containing insoluble elastin, with the exception of most of the strains which were isolated from air samples. This finding is consistent with the putativevirulence role of the elastase (5) in the pathogenesis of aspergillosis in which $A$. fumigatus is the primary agent. However differences in the degree of elastase production were found within strains isolated from the same source.

Several speculations may be drawn from the liquid media results. First of all, the preference of the elastase for a synthetic peptide substrate containing a Phe residue in $P_{1}$ position suggests a chymotrypsinlike activity (17). Our results are consistent with those previously reported by Reichard and coworkers (12). The lack of activity of A.fumigatus elastase with substrates containing Val or Ala residues in $\mathrm{P} 1$ position are consistant with previously results obtained by some of us (8) on alkaline proteinase (called "seaprose") produced by $A$.melleus Yukawa, a nonpathogenic mould belonging to A.aluataceus (formerly A. ochraceus) group (6). The inhibitory profile shows that the A.fumigatus elastase is a serine-proteinase, whereas the ability to degrade insoluble elastin, as suggested by the elastin-c'ongo red assay, is rather weak when compared with that showed by porcine pancreatic elastase. Both of these characteristics are shares by seaprose.

Since A.ochraceus has been reported as human pathogenic only occasionally (11), the homology between $A$ fumigatus elastase and seaprose, the $A$. 
melleus elastase,actually raises concern on the role of A.fumigatus elastase as a virulence factor in human infection, at least as a main factor from this point of view (4-5). This concern recently found a confirmation in a paper of Tony and colleagues (16).

In addition to this functional homology between seaprose and A.fumigatus elastase, our results suggest other speculations. As previously reported $(4,5)$ the $A$. fumigatus elastase acts as inducible enzyme, whose production is particularly evident in the presence of elastin as a substrate. The addition of albumin to elastin further enhances the production of the elastase, but the elastin albumin enriched liquid medium seems less favourable for purification purposes, as deduced from the results corrected by the protein amount (table2).

It has been also reported that the enzyme is induced by presence of collagen as a substrate (9).

Secondly, thecaracterization of the A. fumigatus elastase by different authors (9) yelded somewhat contrasting results. For instance, Monod and coworkers
$(9,12,4)$ reported a $100 \%$ inhibition by PMSF, but no inhibition by either EDTA or TPCK (the latter being a chymotrypsin inhibitor). By contrast, Reichard and coworkers (12) reported a partial inhibition by TPCK, whereas Frosco and coworkers (4) described a $100 \%$ inhibition by $5 \mathrm{mM}$ EDTA, thus suggesting that $A$. fumigatus elastase is a serine proteinasestabilized by ion metals. These discrepancies may imply that $A$.fumigatus could produce more than a single type of elastase.

In our hands, the good agreement between activity of A.fumigatus liquid media on specific synthetic peptide substrate and total proteolytic activity, i.e. azocasein assay, would suggest that the serinechymotrypsin likeelastase is themajor elastase produced by $A$. fumigatus under experimental conditions.

Our results in agreement with Rhodes et al. (13) demonstrated elastinolytic activity in all strains of A. fumigatus isolated from clinical cases, but also a strong elastinolytic activity in saprophytic strains isolated from agricultural soils.

\section{REFERENCES}

1. Barre1, A. J. \& Kirschke, H. (1981). Cathepsin B, Cathepsin H \& Cathepsin, L.Methods Enzymol.80:535-61

2. Bodey, G. P. \& Vartivarian, S. (1989). Aspergillosis. Eur. J. Clin. Microbiol.Infect.Dis. 8: 413-37.

3. Cohen, B. L. (1977). The proteases of Aspergilli. In: Smith, J. E, Pateman, J. A. (eds.) Genetics and Physiology of Aspergillus. London Academic Press : 281-92.

4. Frosco, M. B., Chase, T. Jr. \& Macmilland, J. D. (1992). Purificationand properties of the elastase from Aspergillus fumigatus Infect. Immun. 60:728-34.

5. Kothary, M. H., Chase, T. Jr. \& Macmilland, J. D. (1984). Correlation of elastase production by somestrains of Aspergillus fumigatus with ability to cause pulmonary invasive aspergillosis in mice. Infect. Immun. 43:320-35

6. Kozakiewicz, Z (1989). Aspergillusspecies onstored products. Mycological papers, n:161 - C.A.B. International Mycological Institute, Ferry Lane, Kew, Surrey. 115-25.

7. Lowry, O. H., Rosebrough, N. J., Farr, A. L., \& Randall, R. J. (1951).Protein measurement with the Folin phenol reagent.J. Biol. Chem. 193:265-75

8. Luisetti, M., Piccioni, P. D., Dyne, K. Donnini, M., Bulgheroni, A., Pasturenzi,L., Donnetta, A.M., Peona, V. (1991). Some properties of the alkaline proteinase from Aspergillus melleus. Int. J. Tiss. Reac. 13: 187-92.

9. Monod, M., Togni, G. , Rahalison, L. \& Frenk, E. (1991). Isolation and characterization of an extracellular alka- line protease of Aspergillus fumigatus. J.Med. Micriobiol. $35: 23-38$

10. North, M.J. (1982). Comparative biochemistry of the proteinases of eucaryotic microrganisms. Microbiol. Rev. 46 : 308.

11. Raper, K.B \& Fennel, D.I. (1965). The genus Aspergillus. Baltimore, Williams \& Wilkins Co. $686 \mathrm{pp}$.

12. Reichard, U., Buttner, S., Eiffert, H., Stalb, F. \& Ruchel, R. (1990). Purification and characterization of an extracellular serine proteinase from Asperglllus fumigatus and its detection in tissue. J.Med.Microbiol.33:243-51.

13. Rhodes, J.C., Bode, R.B., McCuan-Kirsch, C.M. (1988). Elastase production inclinicalisolates of Aspergillus. Diagn.Microbiol. Infect. Dis. 10: 165-70.

14, .w............ , Amlung, T.W. \& Miller, M.S. (1990). Isolation and characterization of an elastinolytic proteinase from As pergillus flavus Infect. Immun. $58: 2529-34$.

15. Shotton, D.M. (1970). Elatase. Methods. Enzymol. 19;113-40.

16. Tang, C. M., Cohen, J. Krausz, T. Van Noorden, S. \& Holden, D.W.(1993). Thealkaline proteinase of Aspergillus fumiga. tus is nota virulence determinant in two murine models of invasive pulmonary aspergillosis. Infect. Immun.61:165056.

17. Twumasi, D. Y., Liener, I. E. (1977). Proteases from purulent sputum. Purification and properties of theelastase and chymotrypsin-like enzymes. J. Biol. Chem. 252: 1917-26. 


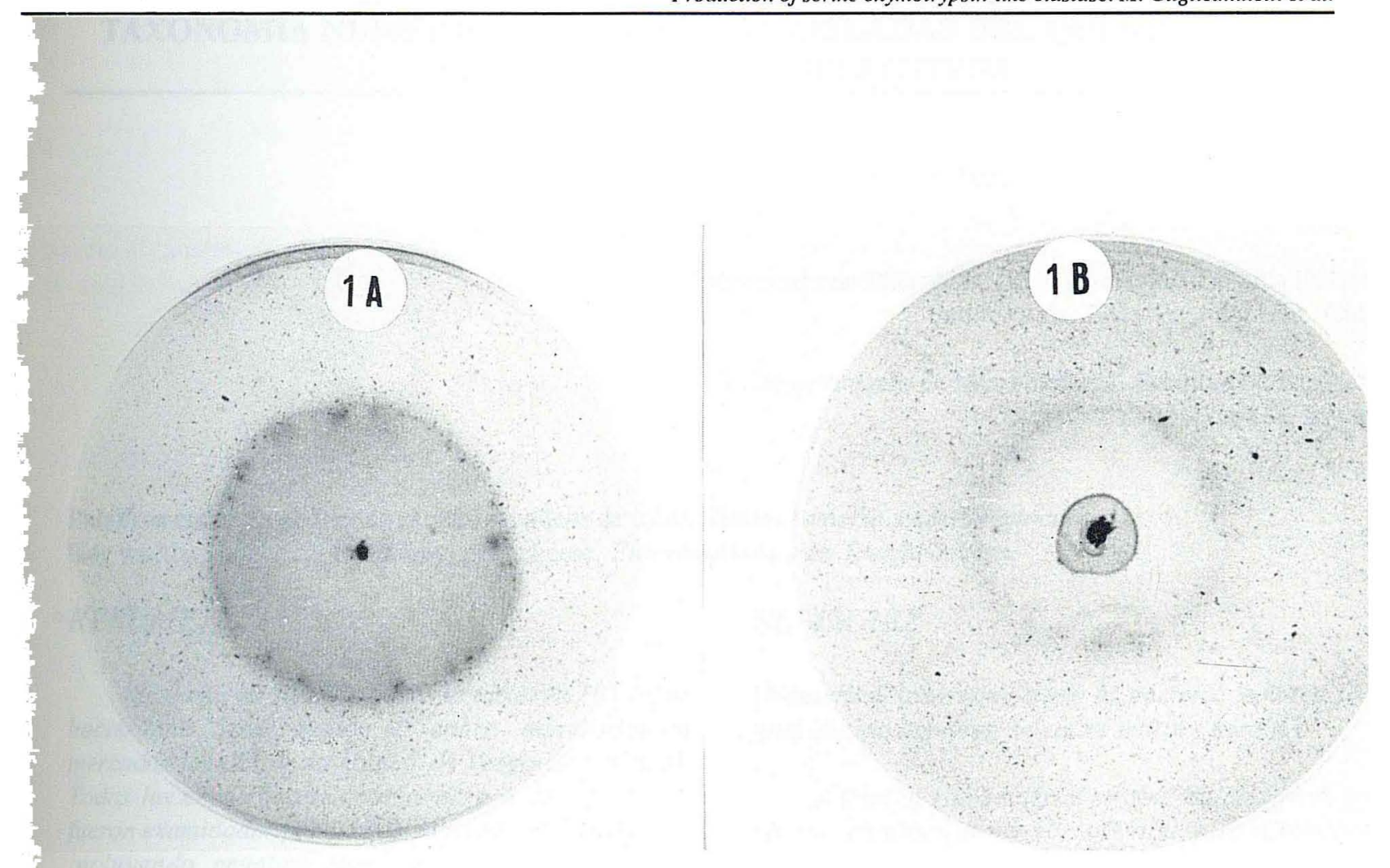

Legends to figures.

Fig.1A.- A.fumigatus growth in elastin solid medium. Same degree of growth and elastinolysis (1A). $\mathrm{TH}$ elastinolysis exceeded the growth (1B).

Fig. 2B.- Elastin congo red degradation by A.fumigatus and porcine pancreatic elastase (P.P.E.) 